\title{
The Effect of Managerial Ability on Corporate Tax Avoidance
}

\author{
Rissa Alfatine Prakosa \\ Department of Accounting \\ Faculty of Economics and Business, Universitas Indonesia \\ Depok, Indonesia \\ alfatinerissa@gmail.com
}

\author{
Dahlia Sari \\ Department of Accounting \\ Faculty of Economics and Business, Universitas Indonesia \\ Depok, Indonesia \\ dahlia-s@ui.ac.id
}

\begin{abstract}
Managerial ability is one of the factors that affect firm strategy and performance. However, most prior studies do not consider these managerial effects on firms. Hence, this paper used Data Envelope Analysis to see whether managers with higher ability can affect corporate tax avoidance. Using panel data from a sample of $\mathbf{1 7 2}$ public firms in Indonesia for five years, this study finds that the higher the managerial ability, the lower the tax avoidance practices occurring in the firm. This result is robust in several sensitivity tests.
\end{abstract}

\section{Keywords - tax avoidance; managerial ability; manager}

\section{INTRODUCTION}

Top managers have an important role in determining corporate strategy and how the firm will perform. Upper Echelons Theory mentions that values, perceptions, and toplevel management knowledge affect corporate outcomes such as firm performance [1-3]. Another organizational behavior that comes from the preference, point of view, and attitude of top managers is tax avoidance [4].

Tax avoidance within the firm has its own costs and benefits. The advantage is that the amount of tax to be paid by the firm is lower; hence, the net profit becomes higher and the amount of wealth transferred to the owner (shareholders) also becomes higher. In addition, the incentives that can be obtained by management also become higher. Meanwhile, the cost of tax avoidance behavior is the cost of tax management and the risk of sanctions due to tax avoidance behavior [5]. If the cost of tax avoidance is greater than the benefits earned from tax avoidance, then the shareholders will not want management to avoid corporate taxes.

Corporate taxes affect and occur in almost all corporate transactions [6], requiring more ability to plan an effective tax strategy. Managerial ability is something that is difficult to judge because the firm's performance could be due to firm fixed effects and not just the managerial ability of top managers [7]. Dyreng, Hanlon, \& Maydew [8] examined and proved that individual firm executives have a significant effect on corporate tax avoidance, but failed to explain certain characteristic relationships to firm executives with tax avoidance. In firms, decision making is not done individually. The board of directors is the party that has the greatest responsibility to determine the strategic decisions of the firm [9]. Some previous research by $[10,11]$ prove that in making decisions there is a shared leadership culture such that other decision-makers within the firm should be seen as one.
Demerjian, Lev, \& McVay [12] found a way to measure the firm's managerial ability quantitatively by excluding the inherent factors of the firm from the firm efficiency and the managerial factors that affect firm efficiency are obtained using Data Envelopment Analysis (DEA). This method has a positive relationship with several other measurement alternatives, but is more focused on managerial factors because it removes firm-specific factors. Demerjian [12] validated these measurements by proving that this method is strongly associated with manager fixed effects and can explain better than other proxies used to measure managerrelated changes in firm performance such as CEO tenure, CEO media mentions, industry-adjusted ROA, CEO compensation, and industry-adjusted stock return.

This research is related to but different from previous research by Koester et al. [7] in the following ways: (1) previous research used a sample of companies listed in Compustat, whereas this study focuses on companies listed in the Indonesia Stock Exchange except for the mining, finance, and utilities sectors; (2) the tax avoidance measurements used in this study apply Current ETR (ETR), Book-Tax Difference (BTD), and Abnormal BTD (Ab_BTD) as proxies, whereas previous research used the Cash ETR method; (3) this study provides a sensitivity analysis by using other measures of managerial ability; i.e., the decile rank of MASCORE and lagged MASCORE; and (4) the results found in this study differ from research by Koester et al. [7].

\section{LITERATURE REVIEW AND HYPOTHESIS DEVELOPMENT}

\section{A. Upper Echelons Theory and Managerial Ability}

Upper Echelons Theory by [3] suggests that top managers see problems and make decisions from perspectives that are influenced by the personal matters of managers such as their experience, values, and the individual nature of managers. Perceptions, values, and other behavioral attributes cannot be measured directly; thus, Pfeffer [13] proposed using demographic characteristics, which are easier data to obtain. However, demographic characteristics are considered to be less comprehensive if used as a proxy for viewing subjective concepts in managers [14]. Research by Dyreng et al. [8] also failed to find out how the demographic characteristics of managers such as age, gender, and tenure affected manager fixed effects, leading to the conclusion that the executive effect on corporate tax avoidance is idiosyncratic. For this reason, this study follows previous research by Koester et al. [7] by attempting to observe executives' effect on corporate 
tax avoidance through a measure of managerial ability that can be quantified according to the model found by Demerjian et al. [12].

Demerjian et al. [12] defined managerial ability as managers' efficiency in transforming the resources available to firms into income relative to their peers. This indicates that managers with higher capabilities will produce relatively larger outputs with a certain amount of input.

\section{B. Agency Theory and Tax Avoidance}

Agency theory states that within the firm there is a separation between ownership and control [15]. The owner (in this case the shareholder) expects that the manager, as the agent, will act in accordance with the wishes of the shareholders. The existence of this separation of ownership leads to the possibility that managers do not act in accordance with the wishes of shareholders. According to Jensen \& Meckling [15], one way to overcome this is to provide incentives to managers if they act in accordance with the wishes of shareholders.

According to Hanlon \& Heitzman [16], tax avoidance is a useful activity because it adds wealth to the owner; therefore, the owner offers more incentives to ensure that managers are willing to make efficient tax decisions, including the decision to avoid taxes. If the incremental benefit of tax avoidance exceeds its cost, then the manager will engage in tax avoidance practices.

\section{Legitimacy Theory, Stakeholder Theory, and Signaling Theory}

Friese, Simon, \& Mayer [17] stated that Corporate Social Responsibility (CSR) is essential for the sustainability of the firm, including taxes paid by companies, because the state will use this tax revenue to finance the public interest. This statement is also supported by the theory of legitimacy and stakeholder theory that if a firm does not have a good relationship in the social and political environment, then the firm will not survive its operation, even if its financial performance is good. Legitimacy is the perception that the activities of an agent are in accordance with prevailing norms, values, and beliefs [18]. The firm seeks legitimacy from various social groups that have varying degrees of influence and strength on companies [19]. These social groups can be government agencies, communities, political groups, trade unions, employees, consumers, and related companies.

Signaling theory suggests that information asymmetry between two parties can be reduced by the way one party with more information signals the other [20]. Signaling theory suggests that the firm is attempting to deliver a message of signal to the public to improve its image and firm value in public's perception. The positive relationship between CSR spending and corporate financial performance is due to a signal that the firm is in good condition and that management expects that the firm's future performance will also be good as indicated by the firm through its CSR spending [21]. From the theory of legitimacy, the theory of stakeholders, and signaling theory, companies view tax payments as a form of social responsibility that is useful to justify their position in social groups, maintain good corporate reputation, and maintain good relationships especially with those involved in the taxation aspect companies (e.g., government and society).

\section{Hypothesis Development}

Corporate taxes affect and occur in almost all corporate transactions [6] and, thus, require more ability to make the right tax planning for the firm. This causes managers with higher capabilities to avoid larger taxes because higher-level managers have a better understanding of their business-both about the firm and the firm's environment and opportunities. This allows managers to better adjust their strategy so as to make more effective tax avoidance decisions [7]. However, there is also the opinion that managers who have a higher ability to manage the firm will use their ability to improve the firm's performance through normal operations [22]. This makes managers less likely to require tax avoidance to make the firm's performance looks good. The higher the managerial ability of a firm, the greater its opportunity cost to avoid taxes because managers are more able to improve the firm's performance from other things that have less risk such as sales and investment [23]. The risk faced here is the uncertainty of the future performance of the firm. Based on previous literature, the following hypothesis can be developed:

Managerial ability has a negative effect on corporate tax avoidance.

\section{RESEARCH METHOD}

Following the research design used in prior studies by Koester et al. [7], we set the models by using the variables of tax avoidance, managerial ability, and control variables as follows:

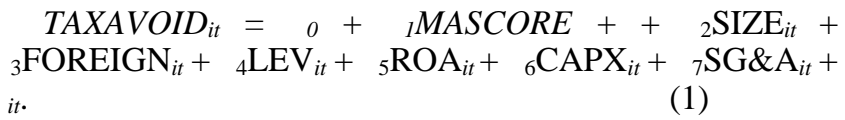

\section{A. Dependent Variable}

We use Current ETR, BTD, and BTD_Ab to measure for tax avoidance. Current ETR measures tax avoidance from current tax expense, so it measures how much the firm should pay for the tax expense compared with its pre-tax income and not only the permanent tax avoidance [24]. A lower Current ETR indicates that higher tax avoidance is applied by the firm. Hence, in this paper, we multiply all Current ETR scores by $(-1)$ to ease the interpretation, which changes the interpretation to a higher Current ETR means higher tax avoidance is practiced by the firm:

$$
\text { Current ETR }=\frac{\text { Current Tax Expense }}{\text { Pre }- \text { tax Accounting Income }}
$$

The second measure of tax avoidance used in this paper is the Book-Tax Difference (BTD), which measures the difference between book and taxable income [25, 26]. Higher BTD means higher tax avoidance practices in the firm. Taxable income information is sometimes unattainable, thus we use current tax expense divided by the applicable tax rate. Therefore, the formula used to measure BTD is:

$$
B T D=\frac{E B T-\frac{\text { Current Tax Expense }}{\text { Tax Rate }}}{\text { Total Assets }}
$$

BTD finds the difference between profit by accounting and taxable income. In this method, the difference between accounting profit and taxable profit can be due to the effort to 
decrease taxable profit and earnings management used to increase accounting income so that the firm's performance seems favorable [27]. To see the tax avoidance factor alone without the earnings management factor in BTD measurements, the third tax avoidance measurement used in this study is the Abnormal BTD by Lim [27] that modified the measurements by Desai \& Dhamarpala [28].

Measurement with Abnormal BTD outlines the components of earnings management on BTD measurements. Lim [27] used discretionary accruals to calculate earnings management because it describes earnings management that is actually done by the firm's management [29, 30]. To calculate the discretionary accruals, Lim [27] used residual values of:

Accrualsit/Assetsit- $1=\alpha(1 /$ Assetsit- $)+\beta_{1}\{(\Delta$ SALEit $\Delta \mathrm{A} /$ Rit $) /$ Assetsit-1) $\}+\beta_{2}($ PPEit/Assetsit-1) + eit

Notes:

Accruals $=$ Total firm accruals. Calculated from Net Income minus cash from operating activities.

Assets $=$ Total assets of the firm at $t_{-1}$

SALE $=$ Difference in sales in years $t$ and $t_{-1}$

$\mathrm{A} / \mathrm{R}=$ Difference in trade receivables in years $t$ and $t_{-1}$ $\mathrm{PPE}=$ Property, plant, and equipment of the firm in year $t$.

We call the residual value of this regression as accrual discretionary (DA-mod). The next step is to regress accrual discretionary (DA-mod) to BTD with the following model:

$$
\mathrm{BTD}_{\mathrm{it}}=\mathrm{b}_{1} \mathrm{DA} \_\bmod _{\mathrm{it}}+\mathrm{u}+\mathrm{e}_{\mathrm{it}}
$$

The residual value in Regression (5) is a component of difference between accounting profit and taxable income, which is only influenced by the tax avoidance factor because the earnings management factor (DA_mod) has been excluded from total BTD. Thus, the residual from this regression is a BTD_Ab variable and is used as one of the proxies to measure tax avoidance in this study.

\section{B. Independent Variable}

This paper uses DEA by Demerjian et al. [12] for managerial ability measurement. DEA measures firm efficiency when a certain amount of output results from a certain amount of input. The more efficient a firm is, the more output it generates given the same input. The model used is the optimization model:

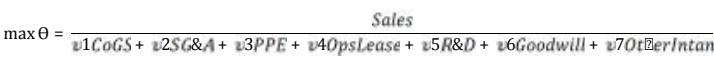

Data for each variable in this model are taken from Eikon Reuters Data Stream and the firm's annual report. Sales is the output in this model. The input has seven variables. Cost of goods sold is used as an input because in order to generate product sales as output, firms need to spend a certain amount of money on raw materials, direct labor, and other expenses to produce the product.

Selling, general, and administrative expenses (SG\&A) are costs that companies pay to generate more revenues. An example of SG\&A is advertising cost, which is used to increase consumer awareness of the product and, thereby, generates more revenue for the firm. Property, plant, and equipment (PPE) in this model is Net PPE, i.e., the undepreciated portion of PPE assets. Operating Lease
(OpsLease) is also used in this model because not all firms buy all their assets and report it as a part of PPE. Some firms lease their assets to run their operation. Although these assets are used on a lease basis, they can still generate revenue just like PPE. Not every firm in Indonesia discloses its operating lease, but this variable is still used in this paper because, based on research by Demerjian et al. [12], DEA measured without the operating lease variable yields the same qualitative and quantitative result; therefore, whether or not these variables are used in the model has no significant effect on DEA measurement.

Research and development expense (R\&D) is used because managers who have higher ability would be able to estimate how much they should budget for R\&D cost. The R\&D variable in this paper is Net R\&D. Goodwill is the excess of purchase price of a business acquisition and reflects intangible assets. Other intangible assets (OtherIntan) is also used as an input in this model.

To measure DEA, we use "add-ins" in Microsoft Excel. Add-ins is chosen because of its ease and DEA measurement using add-ins has the same result as measuring DEA using other software such as DEA Open Source. To calculate firm efficiency by the DEA method, we first group Decision Making Unit (DMU) based on the industry according to Thomson Reuters. This grouping is necessary because firms in the same industry have a similar input-output relationship. They also have more comparable chance to make their performance more efficient. In this grouping, DMUs are grouped just by their industry and not by time because many DMUs are required to calculate DEA (minimum of 100 DMUs) [12].

Second, DEA varies the weights for each DMU to maximize Model (6) relative to its industry. These weights are restricted to be non-negative. Third, optimum weight results in maximizing Model (6) in each DMU are then multiplied by each input/outputs and then all inputs for each DMU are summed. The sum of outputs is then divided by the sum of inputs, resulting in the efficiency ratio for each DMU. Fourth, this ratio is then divided by the highest ratio in its group; thus, the highest ratio in the group will get an efficiency score of 1 . The efficiency score ranges from 0 to 1 , with 1 meaning that the DMU is efficient relative to its industry.

Model (6) measure firm efficiency and comprises firmrelated and managerial factors. To calculate the managerial factor, we should exclude the firm-related factor. Following [12], we perform a tobit regression for firm efficiency and firm-related efficiency factors.

Firm Efficiency $=\alpha+\beta_{1} \ln$ (Total Assets)i $+\beta_{2}$ Market Sharei $+\beta_{3}$ Free Cash Flow Indicatori $+\beta_{4} \ln ($ Age $) i+\beta_{5}$ Business Segment Concentrationi $+\beta_{6}$ Foreign Currency Indicatori $+\varepsilon_{\mathrm{i}}$

The result of this regression is the effect of firm-related factors on firm efficiency. Thus, the residual of this regression is the firm efficiency from the managerial factors or managerial ability (MASCORE). The higher the MASCORE is, the higher the managerial ability of the firm.

\section{Control Variables}

We use six control variables to avoid measurement biases. The usage of these control variables is meant to decrease the possibility of MASCORE including these variables' effect in tax avoidance measurement. Control variables used follow 
those in Koester et al. [7] with some modifications. We control for firm size, foreign operations, leverage, return on assets, capital expenditures, and SG\&A as control variables. We exclude R\&D, Intangible assets, and NOL decrease due to data unavailability. We also replace advertising expense with SG\&A because it includes advertising expense and the data are more available than advertising expense data. Koester et al. [7] also found that there is no significant difference between using advertising expense or SG\&A on this measurement (see Appendix 1 for further explanation of the control variables).

\section{RESULT AND DISCUSSION}

\section{A. Results of Sampling}

In this paper we use a purposive sampling method with these criteria: (1) publicly traded firm; (2) not in the mining, financial, or utilities sector; (3) has positive earnings before tax; (4) has a minimum of twenty firms in the same industry; (5) has complete data to measure both managerial ability and tax avoidance. All data were extracted from Thomson Reuters Data Stream and the firms' financial report.

TABLE I. SAMPLE SELECTION

\begin{tabular}{|l|r|}
\hline Criteria & Observations \\
\hline Observations from 2012-2016 & 2964 \\
\hline Including in financial, mining, and utilities sectors & $(1071)$ \\
\hline Including industries with <20 firms & $(928)$ \\
\hline Has negative capital & $(104)$ \\
\hline Has negative pre-tax income & $(121)$ \\
\hline Incomplete data & $(76)$ \\
\hline Total Observations & 664 \\
\hline
\end{tabular}

The appropriateness of the sample is reviewed using a histogram and stem-and-leaf graph. Nineteen outliers are deleted from the sample, resulting in a total of 645 firm-year observations for analysis.

\section{B. Descriptive Statistics}

Table 2 shows the mean and standard deviation of the sample's MASCORE are 0.8677195 and 0.0311558 , respectively. This represents an average of about $86 \%$ of firm efficiency and low variation. The Book-Tax Difference (BTD) has an average and standard deviation of 0.0069619 and 0.0433805 , respectively. A positive BTD indicates that the average sample firm practices tax avoidance but to a lesser degree. Abnormal BTD is an average of 0.0082047 and has a standard deviation of 0.004696 , which means low variation in Abnormal BTD variables. ETR has an average value and standard deviation of 0.2585928 and 0.1943214 , respectively, with the highest variation among the three measures of tax avoidance.

\section{Regression Results Analysis}

The regression results using ETR, BTD, and BTD_Ab (Table 3) show a significant negative result. The regression result for BTD has a significance level of $p<0.01$ while those for ETR and BTD_Ab have a significance level of $p<0.05$. Generally, these three result show that the higher the managerial ability in a firm, the less tax avoidance practices performed by the firm. The difference in significance is probably due to a different approach to the BTD proxy. The ETR proxy measures the ratio of the tax rate that a firm should pay against its pre-tax income, whereas Abnormal BTD measures the difference in accounting profit and taxable income by excluding the earnings management factor.

Broadly speaking, these two measurements reflect only the aspects of taxation alone. Meanwhile, tax avoidance by BTD proxy measures the difference in accounting profit with taxable income caused by tax avoidance and earnings management factors [27].

TABLE II. MAIN MODEL REgRESSION RESULT

\begin{tabular}{|c|c|c|c|c|c|}
\hline Variable & $N$ & Mean & Std.Dev & Min & Max \\
\hline MASCORE & 645 & 0.8677195 & 0.0311558 & 0.8020587 & 1.040636 \\
\hline Btd & 645 & 0.0069803 & 0.0434116 & -0.1301815 & 0.3351935 \\
\hline Btd_DA & 645 & 0.0081948 & 0.004693 & -0.0222274 & 0.0332122 \\
\hline ETR & 645 & -0.2555078 & 0.1943214 & -1.776702 & 0.3464138 \\
\hline Size & 645 & 21.58564 & 1.433211 & 16.86177 & 25.22027 \\
\hline Foreign & 645 & 0.2418605 & 0.4285425 & 0 & 1 \\
\hline Leverage & 645 & 0.1454372 & 0.1544498 & 0 & 0.9807375 \\
\hline ROA & 645 & 0.0855315 & 0.07430057 & 0 & 52.09 \\
\hline Capex & 645 & 0.3199651 & 0.4846531 & 0 & 4.598954 \\
\hline SG\&A & 645 & 0.1369421 & 0.166059 & 0.0008467 & 1.066734 \\
\hline
\end{tabular}


TABLE III. REGRESSION RESULT USING MASCORE

\begin{tabular}{|c|c|c|c|c|c|c|c|}
\hline \multirow{3}{*}{ Variable } & \multirow{3}{*}{ Prediction } & \multicolumn{6}{|c|}{ Tax Avoidance } \\
\hline & & \multicolumn{2}{|l|}{ ETR } & \multicolumn{2}{|l|}{ BTD } & \multicolumn{2}{|l|}{ BTD_Ab } \\
\hline & & Coefficient & $P$ Value & Coefficient & $P$ value & Coefficient & $P$ Value \\
\hline Intercept & $+/-$ & $0.69269 * *$ & $(0.020)$ & $0.41041 * *$ & $(0.035)$ & 0.00506 & $(0.418)$ \\
\hline MASCORE & - & $-0.62557 * *$ & $(0.013)$ & $-0.34441 * * *$ & $(0.000)$ & $-0.01576^{* *}$ & $(0.031)$ \\
\hline Size & - & $-0.02152 * * *$ & $(0.005)$ & -0.00534 & $(0.254)$ & 0.00077 & $(0.183)$ \\
\hline Foreign & - & -0.00875 & $(0.285)$ & $0.00551 * *$ & $(0.024)$ & 0.00022 & $(0.201)$ \\
\hline Leverage & + & 0.03846 & $(0.260)$ & -0.03164 & $(0.189)$ & $0.00451 * *$ & $(0.013)$ \\
\hline ROA & + & $0.00919 * * *$ & $(0.000)$ & $0.00335 * * *$ & $(0.000)$ & 0.00002 & $(0.292)$ \\
\hline Capex & + & 0.01535 & $(0.169)$ & -0.00554 & $(0.115)$ & 0.00040 & $(0.133)$ \\
\hline SG\&A & - & $-0.22603 * * *$ & $(0.001)$ & $-0.09349^{* *}$ & $(0.039)$ & $-0.00628^{*}$ & $(0.067)$ \\
\hline $\mathrm{N}$ & & \multicolumn{2}{|l|}{645} & \multicolumn{2}{|l|}{645} & \multicolumn{2}{|l|}{645} \\
\hline $\mathrm{R}^{2}$ & & \multicolumn{2}{|l|}{0.0983} & \multicolumn{2}{|l|}{0.1338} & \multicolumn{2}{|l|}{0.0373} \\
\hline
\end{tabular}

Managerial ability has a negative effect on earnings management [22]. This may lead to a higher significance level with BTD proxy, which also incorporates earnings management than the effect of managerial ability on tax avoidance with Abnormal BTD proxy that does not include the earnings management component. Meanwhile, tax avoidance by ETR proxy does not measure tax avoidance by the difference between accounting profit and taxable income, but on the ratio of current tax expense compared with pre-tax income. Hence, the hypothesis is accepted.

There are several explanations for the results of this regression. First, the higher the managerial ability of a firm, the higher the opportunity cost of tax avoidance relative to that of improving firm performance through activities other than tax avoidance [23]. This is because the higher the managerial ability, the higher the tax and non-tax costs of tax avoidance. This is also reinforced by Graham, Hanlon, Shelvin, \& Shroff [31], which states that tax avoidance activities are activities that have a significant cost.

Second, higher-ability managers have sufficient capability to produce better output with a certain number of inputs than managers with lower abilities. Thus, because tax avoidance activities have their own non-tax costs, higherability managers will choose to increase output by other means than tax avoidance.

Third, previous research [32] found that the utilization of investment opportunities is better able to be performed by managers with higher ability; thus, managers with higher managerial skills will choose to improve the firm's performance by leveraging investment opportunities rather than using tax avoidance because investment is considered to have a smaller cost.

Fourth, managers may avoid taxes for their firms to gain incentives from lower amount of tax payable, but this will affect the firm's reputation, which impacts in the longer term.

For example, Hanlon \& Slemrod [33] found that when there is news about the firm's involvement in tax avoidance practices, on average, the firm's stock price becomes lower. Reputation ranked second as a reason why companies do not avoid taxes [32]. Reputation is something that is considered important by $69 \%$ of executives based on a survey by [31].
Therefore, firms with higher managerial capabilities will engage in lower tax avoidance.

Fifth, research by Holland, Lindop, \& Zainudin [34] found that managers considered tax avoidance could threaten the legitimacy of the firm. The theory of legitimacy states that in order for a firm to continue its operations, the firm as a whole must be considered legal by key factors of evaluation [13]. Higher-ability managers will consider the sustainability of the firm by engaging less in tax avoidance practices that threaten the firm's legitimacy.

The findings in this study differ from those in previous studies by Koester et al. [7], who found that the higher the managerial ability, the more the firm was involved in tax avoidance activities. This difference may occur because the benefits derived from tax avoidance activities in their research sample exceeded the costs incurred, whereas benefits obtained by firms in the present sample are less than the cost that can be generated. Previous research used samples of public firms in United States, whereas this study used a sample of public firms in Indonesia. In the years 20122016 explored in this study, the United States used a flat rate of $35 \%$ while Indonesia imposed a flat rate of $25 \%$ corporate tax. This may cause companies in the United States to be more compelled to avoid taxes because the savings can be considered to exceed the potential tax and non-tax costs. Mcclure [35] in his research found that tax-avoiding firms (marked with smaller ETRs), avoided taxes because the nontax costs they had to face were relatively smaller than other companies that decided not to avoid taxes.

Although these findings differ from those of Koester et al. [7], the findings here are consistent with research by Francis et al. [32] and Park et al. [23] who found that managerial ability was significantly negatively related to corporate tax avoidance. Both studies used Asian firms as their sample

\section{Sensitivity Analysis}

\section{1) Managerial Ability Using Managerial Ability Score} Decile Rank

The proxy of managerial ability used in this study is the score of managerial ability. Demerjian [12] also used the rank of decile (MA rank) per industry from a managerial ability score to facilitate comparison. This measurement will be used as an alternative measurement of managerial ability to test the 
sensitivity of this research. Therefore, we use the model as follows:

TaxAvoidance $=\alpha_{0}+\beta_{1} \mathrm{MA}_{-} \mathrm{Rank}_{i t}+\beta_{2} \mathrm{SIZE}_{i t}+$ $\beta_{3}$ FOREIGN $_{i t}+\beta_{4} \mathrm{LEV}_{i t}+\beta_{5} \mathrm{ROA}_{i t}+\beta_{6} \mathrm{CAPX}_{i t}+\beta_{7} \mathrm{SG}_{\mathrm{S}} \mathrm{A}_{i t}$ + FirmFixedEffect $+\varepsilon_{i t}$

The result of Regression (8) in Table 4 shows that managerial ability with decile rank proxy has significant negative effect $(p<.0 .01)$ on tax avoidance with BTD proxy and has a significant negative effect $(p<0.05)$ on tax avoidance with ETR and Abnormal BTD proxies. In brief, these results are similar to regressions using a proxy of managerial ability scores.

$\mathrm{R}^{2}$ by using a decile rank of managerial ability both with tax avoidance measurements through the calculation of ETR, $\mathrm{BTD}$, or Abnormal BTD is smaller than the $\mathrm{R}^{2}$ model of managerial ability scores. That is, for a sample of Indonesian public firms, the model of managerial ability scores is more explanatory than the decile rank model

TABLE IV. REgRESSION RESUlts USING MANAGERIAL ABILITY DECILE RANK

\begin{tabular}{|c|c|c|c|c|c|c|c|}
\hline \multirow{3}{*}{ Variable } & \multirow{3}{*}{ Prediction } & \multicolumn{6}{|c|}{ Tax Avoidance } \\
\hline & & \multicolumn{2}{|l|}{ ETR } & \multicolumn{2}{|l|}{ BTD } & \multicolumn{2}{|l|}{ BTD_Ab } \\
\hline & & Coefficient & P Value & Coefficient & $\mathrm{P}$ value & Coefficient & P Value \\
\hline Intercept & $+/-$ & 0.18031 & $(0.169)$ & 0.12637 & $(0.230)$ & -0.00948 & $(0.298)$ \\
\hline Size & - & $-0.02159 * * *$ & $(0.005)$ & -0.00589 & $(0.250)$ & 0.00085 & $(0.145)$ \\
\hline Foreign & - & -0.00877 & $(0.266)$ & $0.00589^{* *}$ & $(0.017)$ & 0.00023 & $(0.189)$ \\
\hline Leverage & + & 0.04021 & $(0.250)$ & -0.02987 & $(0.199)$ & $0.00456 * *$ & $(0.013)$ \\
\hline Capex & + & 0.01508 & $(0.173)$ & -0.00592 & $(0.100)$ & 0.00038 & $(0.014)$ \\
\hline SG\&A & - & $-0.23021 * * *$ & $(0.001)$ & $-0.10056^{* *}$ & $(0.026)$ & $-0.00644 *$ & $(0.061)$ \\
\hline $\mathrm{N}$ & & 645 & & 645 & & 645 & \\
\hline $\mathrm{R}^{2}$ & & 0.0946 & & 0.1374 & & 0.0281 & \\
\hline \multicolumn{8}{|c|}{$\begin{array}{l}\text { Two-tailed test. } \\
\text { Significance levels: } * p<0.1 ; * * p<0.05 ; * * * p<0.01\end{array}$} \\
\hline \multicolumn{8}{|c|}{$\begin{array}{l}\text { Notes: } \\
\text { MA Rank = Decile rank of managerial ability score using DEA. } \\
\text { Size = Firm size. Measured by calculating the natural logarithm of Total Assets. } \\
\text { Foreign = Foreign operations of the firm. Rated } 1 \text { if the firm has revenue from foreign operations and } 0 \text { otherwise. } \\
\text { Leverage = Calculated by dividing Total Debt by Total Assets of the firm. } \\
\text { ROA = Net Income divided by Total Assets of the firm. } \\
\text { Capex = Capital expenditure divided by net property, plant, and equipment (PPE). } \\
\text { SG\&A = Sales, general, and administrative expenses divided by Total Assets. }\end{array}$} \\
\hline
\end{tabular}

TABLE V. REGRESSION RESUlTS USING LAGGED MANAGERIAL ABILITY SCORE

\begin{tabular}{|c|c|c|c|c|c|c|c|}
\hline \multirow{3}{*}{ Variable } & \multirow{3}{*}{ Prediction } & \multicolumn{6}{|c|}{ Tax Avoidance } \\
\hline & & \multicolumn{2}{|l|}{ ETR } & \multicolumn{2}{|l|}{ BTD } & \multicolumn{2}{|l|}{ BTD_Ab } \\
\hline & & Coefficient & P Value & Coefficient & $\mathrm{P}$ value & Coefficient & P Value \\
\hline Intercept & $+/-$ & 0.44515 & $(0.143)$ & $0.50656 * *$ & $(0.043)$ & 0.02196 & $(0.277)$ \\
\hline Lagged MA & - & $-0.49553 *$ & $(0.082)$ & $-0.35736 * * *$ & $(0.001)$ & $-0.01646^{*}$ & $(0.080)$ \\
\hline Size & - & $-0.01661 *$ & $(0.059)$ & -0.00999 & $(0.162)$ & 0.00004 & $(0.489)$ \\
\hline Foreign & - & $0.03439 * *$ & $(0.061)$ & $0.00943 * * *$ & $(0.001)$ & -0.00019 & $(0.292)$ \\
\hline Leverage & + & 0.09982 & $(0.130)$ & 0.01398 & $(0.365)$ & $0.00576^{* * *}$ & $(0.009)$ \\
\hline Capex & + & 0.03642 & $(0.150)$ & 0.00649 & $(0.183)$ & $0.00198 * * *$ & $(0.006)$ \\
\hline SG\&A & - & $-0.29985 * * *$ & $(0.000)$ & $-0.50656^{* *}$ & $(0.043)$ & -0.00669 & $(0.129)$ \\
\hline $\mathrm{N}$ & & 645 & & 645 & & 645 & \\
\hline $\mathrm{R}^{2}$ & & 0.1013 & & 0.1594 & & 0.0765 & \\
\hline \multicolumn{8}{|c|}{$\begin{array}{l}\text { Two-tailed test. } \\
\text { Significance Level: } * p<0.1 ; * * p<0.05 ; * * * p<0.01\end{array}$} \\
\hline \multicolumn{8}{|c|}{$\begin{array}{l}\text { Notes: } \\
\text { Lagged = Lagged score of managerial ability using DEA. } \\
\text { Size = Firm size. Measured by calculating the natural logarithm of Total Assets. } \\
\text { Foreign = Foreign operations of the firm. Rated } 1 \text { if the firm has revenue from foreign operations and } 0 \text { otherwise. } \\
\text { Leverage = Calculated by dividing Total Debt by Total Assets of the firm. } \\
\text { ROA = Net Income divided by Total Assets of the firm. } \\
\text { Capex = Capital expenditure divided by net property, plant, and equipment (PPE). } \\
\text { SG\&A = Sales, general, and administrative expenses divided by Total Assets. }\end{array}$} \\
\hline
\end{tabular}

\section{E. Managerial Ability Using Lagged Managerial Ability Score}

A second sensitivity analysis test is done by replacing the measurement of managerial ability score (MASCORE) into lagged MASCORE (lagged MA). According to Francis et al. [32], using managerial information from previous years is important because tax avoidance is a long-term strategy that takes time to get results $[36,16]$. In this study, we use a one- 
year lag with the assumption that the result from strategy and decisions taken by managers in year $t_{0}$ will be visible on firm's taxation at $t_{1}$. Therefore, in this sensitivity test, the following model is used:

TaxAvoidance $=\alpha 0+\beta$ 1laggedMAit $+\beta 2$ SIZEit + $\beta 3$ FOREIGNit $+\beta 4$ LEVit $+\beta 5$ ROAit $+\beta 6$ CAPXit + $\beta 7$ SG\&Ait + FirmFixedEffect $+\varepsilon i t$.

The result of regression using this lagged MA (Table 5) shows significant negative results $(p<0.01)$ for the effect of managerial ability on tax avoidance of firms with BTD proxy. The regression result of the lagged MASCORE on tax avoidance with ETR and Abnormal BTD proxy showed significant negative result $(\mathrm{p}<0.1)$.

Broadly speaking, the results from measurements with lagged MA models are similar to those measured using a concurrent MASCORE model. Nevertheless, the lagged MA model's significance level to tax avoidance with the ETR and Abnormal BTD is below the level of significance with the MASCORE model and the MA rank model.

$\mathrm{R} 2$ on the measurement with the lagged MA model is higher than R2 in the MASCORE model and MA rank. That is, the measurement of managerial ability with the lagged MA model is more explaining to the sample companies in Indonesia.

\section{CONCLUSION AND IMPLICATION}

The purpose of this study was to examine the effect of managerial ability on tax avoidance. Few previous studies have examined the relationship between managerial ability and tax avoidance. Francis et al. [32] and Park et al. [23] found a negative relationship between managerial ability and tax avoidance, whereas Koester et al. [7] found a positive relationship between managerial ability and corporate tax avoidance. The results of this study alone show evidence of significant negative effect of managerial ability on tax avoidance.

This study explains the significant negative relationships found with some of the findings from previous studies. For managers with higher managerial skills, because these managers have sufficient capability to improve the firm's performance by streamlining output with available resources, tax avoidance practices are assessed to have greater opportunity cost and lower benefits [23]. In terms of investments, for example, higher-ability managers can utilize investment opportunities better than those with lower managerial abilities [32]. Tax avoidance practices also affect the firm's reputation as evidenced by the decline in the average stock price of the firm when there is news that the firm is engaged in tax avoidance activities [33]. Tax avoidance is also considered an activity that threatens the legitimacy of the firm [34], whereas according to the theory of legitimacy, to be able to continue operations and maintain the sustainability of the firm, the operations of the firm and the firm as a whole must be considered legitimate by the parties involved in by the firm's activities [13].

This research has several limitations. First, the DEA calculations depend on imperfect industry classification. The sample is divided into several industries according to Thomson Reuters. There are several other industry classifications such as JASICA and SIC. Subsequent research can utilize other industry classifications. Second, although considered an accurate measure of managerial ability [12], some weaknesses in DEA remain such as not including the decision factors taken by managers in daily operations [7]. Further research can compare the effect of managerial ability on tax avoidance using DEA and other proxies such as industry-adjusted ROA, industry-adjusted stock return, CEO tenure, CEO media mention, and CEO compensation. Third, $[8,22]$ found that individual managers and manager characteristics affect firms' tax avoidance; however, this research does not consider the managerial effect on tax avoidance in relation to individual manager characteristics. Further research can compare the effect of managerial ability and managerial characteristics on firms' tax avoidance. Fourth, the taxation provisions in each country generate both costs and benefits to avoiding taxes, which varies among countries. This may affect managerial decisions in tax avoidance; thus, further research can compare the effect of managerial ability on tax avoidance by firms from several countries with different tax provisions.

\section{ACKNOWLEDGMENT}

We thank the reviewers in Asia Pacific Research in Social Sciences and Humanities Conference (APRISH) 2018 for giving us feedbacks that greatly improved the manuscript.

\section{REFERENCES}

[1] Carpenter, M. A., Geletkancz, M. A., \& Sanders, W. G. (2004). Upper echelons research revisited: Antecedents, elements, and consequences of top management team composition. Journal of Management. 30(6), 749-778. https://doi.org/10.1016/j.jm.2004.06.001

[2] Chatterjee, A., \& Hambrick, D. C. (2007). It's all about me: Narcissistic chief executive officers and their effects on company strategy and performance. Administrative Science Quarterly, 52(3), 351--386. https://doi.org/10.2189/asqu.52.3.351

[3] Hambrick, D. C., \& Mason, P. A. (1984). Upper echelons: The organization as a reflection of its top managers. Academy of Management Review, 9(2), 193-206. https://doi.org/10.5465/AMR. 1984.4277628

[4] Hsieh, T.-S., Wang, Z., \& Demirkan, S. (2016). Overconfidence and tax avoidance: The role of CEO and CFO interaction.

[5] Cen, L., Maydew, E. L., Zhang, L., \& Zuo, L. (2016). Customersupplier relationships and corporate tax avoidance. Journal of Financial Economics. 123(2), 377-394.

[6] Kubick, T. R., \& Lockhart, G. B. (2017). Overconfidence, CEO awards, and corporate tax aggressiveness. Journal of Business Finance and Accounting, 44(5-6), 728-754. https://doi.org/10.1111/ jbfa.12237

[7] Koester, A., Shevlin, T., \& Wangerin, D. (2016). The role of managerial ability in corporate tax avoidance. Management Science, 63(10), 3285-3310.. https://doi.org/10.1287/mnsc.2016.2510

[8] Dyreng, S. D., Hanlon, M., \& Maydew, E. L. (2010). The effects of executives on corporate tax avoidance. Accounting Review, 85(4), 1163-1189. https://doi.org/10.2308/accr.2010.85.4.1163

[9] Rose, J. M. (2007). Corporate directors and social responsibility: Ethics versus shareholder value. Journal of Business Ethics, 73(3), 319-331. https://doi.org/10.1007/s10551-006-9209-z

[10] Ensley, M. M. D., \& Pearce, C. L. C. (2001). Shared cognition in top management teams: implications for new venture performance. Journal of Organizational Behavior, 22(2), 145-160. https://doi.org/ 10.1002/job.83

[11] Perry, M., Pearce, C., \& Sims, H. (1999). Empowered selling teams: How shared leadership can contribute to selling team outcomes. Journal of Personal Selling and Sales Management, 19, 35-52.

[12] Demerjian, P., Lev, B., \& McVay, S. (2012). Quantifying managerial ability: A new measure and validity tests. Management Science, 58(7), 1229-1248. https://doi.org/10.1287/mnsc.1110.1487 
[13] Pfeffer, J. (1981). Some consequences of organizational demography: Potential impacts of an aging work worce on formal organizations. Academic Press, 291-329.

[14] Bertrand, M., \& Schoar, A. (2003). Managing with style: The effect of managers on firm policies. The Quarterly Journal of Economics, 118(4), 1169-1208. https://doi.org/10.1162/003355303322552775

[15] Jensen, M. C., \& Meckling, W. H. (1976). Theory of the firm: Managerial behavior, agency costs and ownership structure. Journal of Financial Economics, 3(4), 305-360. https://doi.org/10.1016/0304405X(76)90026-X

[16] Hanlon, M., \& Heitzman, S. (2010). A review of tax research. Journal of Accounting and Economics, 50(2-3), 127-178. https://doi.org/10.1016/j.jacceco.2010.09.002

[17] Friese, A., Simon, L., \& Mayer, S. (2008). Taxation and Corporate Governance-The State of the Art. Springer.

[18] Ginzel, L. E., Kramer, R. M., \& Sutton, R. I. (1993). Organizational impression management as a reciprocal influence process: The neglected role of the organizational audience. Research in Organizational Behavior, 15, 227-266.

[19] Waller, D. S., \& Lanis, R. (2009). Corporate social responsibility (CSR) disclosure of advertising agencies: An exploratory analysis of six holding companies' annual reports. Journal of Advertising, 38(1), 109-122. https://doi.org/10.2753/JOA0091-3367380107

[20] Spence, M. (1973). Job market signaling. The Quarterly Journal of Economics, 87(3), 355. https://doi.org/10.2307/1882010

[21] Lys, T., Naughton, J. P., \& Wang, C. (2015). Signaling through corporate accountability reporting. Journal of Accounting and Economics, 60(1), 56-72. https://doi.org/10.1016/j.jacceco.2015.03.001

[22] Huang, X. (Sharon), \& Sun, L. (2017). Managerial ability and real earnings management. Advances in Accounting, 39, 91-104. https://doi.org/10.1016/j.adiac.2017.08.003

[23] Park, J., Ko, C. Y., Jung, H., \& Lee, Y. (2015). Asia-Pacific journal of accounting \& managerial ability and tax avoidance: evidence from Korea, (April), 37-41. https://doi.org/10.1080/16081625.2015.1017590

[24] Salihu, I. A., Sheikh Obid, S. N., \& Annuar, H. A. (2013). Measures of corporate tax avoidance: Empirical evidence from an emerging economy. International Journal of Business and Society, 14(3).
[25] Guenther, D. A. (2014). Measuring corporate tax avoidance: Effective tax rates and book-tax differences. Working Paper. Retrieved from http://papers.ssrn.com/sol3/papers.cfm?abstract_id=2478952

[26] Manzon, Jr., G. B., \& Plesko, G. A. (2001). The relation between financial and tax reporting measures of income. SSRN Electronic Journal. https://doi.org/10.2139/ssrn.264112

[27] Lim, Y. (2011). Tax avoidance, cost of debt and shareholder activism: Evidence from Korea. Journal of Banking and Finance, 35(2), 456470. https://doi.org/10.1016/j.jbankfin.2010.08.021

[28] Desai, M. A., \& Dharmapala, D. (2006). Corporate tax avoidance and high-powered incentives. Journal of Financial Economics, 79(1), 145179. https://doi.org/10.1016/j.jfineco.2005.02.002

[29] Dechow, P. M., Sloan, R. G., \& Sweeney, A. P. (1995). Detecting earnings management. The Accounting Review, 70(2), 193-225. https://doi.org/10.2307/248303

[30] Kothari, S. P., Leone, A. J., \& Wasley, C. E. (2005). Performance matched discretionary accrual measures. Journal of Accounting and Economics, 39(1), 163-197. https://doi.org/10.1016/j.jacceco.2004.11.002

[31] Graham, J. R., Hanlon, M., Shevlin, T., \& Shroff, N. (2014). Incentives for tax planning and avoidance: Evidence from the field. Accounting Review, 89(3), 991-1023. https://doi.org/10.2308/accr-50678

[32] Francis, B., Sun, X., \& Wu, Q. (2013). Managerial ability and tax avoidance. Social Science Research Network, SSRN 23486, 1-56. https://doi.org/10.2139/ssrn.2348695

[33] Hanlon, M., \& Slemrod, J. (2009). What does tax aggressiveness signal? Evidence from stock price reactions to news about tax shelter involvement. Journal of Public Economics, 93(1-2), 126-141. https://doi.org/10.1016/j.jpubeco.2008.09.004

[34] Holland, K., Lindop, S., \& Zainudin, F. (2016). Tax avoidance: A threat to corporate legitimacy? An examination of companies' financial and CSR reports. British Tax Review, (3), 310-338. https://doi.org/10.1017/CBO9781107415324.004

[35] Mcclure, C. (2018). Determinants of Tax Avoidance, (January).

[36] Dyreng, S. D., Hanlon, M., \& Maydew, E. L. (2008). Long-Run Corporate Tax Avoidance, 83(1), 61-8 


\section{Appendix 1. Control Variables}

\begin{tabular}{|l|l|}
\hline Variable & \multicolumn{1}{|c|}{ Description } \\
\hline SIZE & Natural logarithm of Total Assets \\
\hline Foreign & Firm's foreign operation. Rated 1 if the firm has foreign revenue and 0 otherwise \\
\hline Leverage & Total long-term debt divided by Total Assets \\
\hline ROA & Net Income divided by Total Assets \\
\hline Capex & Capital expenditure divided by firm's property, plant, and equipment \\
\hline SG\&A & Selling, general, and advertising expense divided by Total Assets \\
\hline
\end{tabular}

